\title{
Organochlorine Pollutants within a Polythermal Glacier in the Interior Eastern Alaska Range
}

\author{
K.R. Miner ${ }^{1}$, S. Campbell 2,3, C. Gerbi ${ }^{2}$, A. Liljedahl', T. Anderson', B.L. Perkins ${ }^{6}$, S. Bernsen ${ }^{2}$, \\ K.J. Kreutz ${ }^{1,2}$ \\ 1 Climate Change Institute, University of Maine, ME USA; Kimberley.Miner@Maine.edu \\ 2 School of Earth and Climate Sciences, University of Maine, ME USA; seth.campbell@maine.edu \\ karl.kreutz@maine.edu,Christopher.gerbi@maine.edu \\ 3 Department of Earth and Space Sciences, University of Washington, WA USA \\ 4 Water and Environmental Research Center (WERC), University of Alaska, AK USA; akliljedahl@alaska.edu \\ 5 College of Science and Humanities, Husson University, ME USA; AndersonT@husson.edu \\ 6 School of Food and Agriculture, University of Maine, ME USA; Lewis_Perkins@umit.maine.edu \\ * Correspondence: Kimberley.Miner@Maine.edu; Tel.: +1 703-428-3782
}

\begin{abstract}
To assess the presence of organochlorine pollutants (OCP) in Alaskan sub-Arctic latitudes, we analyzed ice core and meltwater samples from Jarvis Glacier, a polythermal glacier in Interior Alaska. Jarvis Glacier is receding as atmospheric warming continues throughout the region, increasing opportunity for OCP transport both englacially and into the proglacial watershed. Across glacial meltwater and ice core samples we utilize solid-phase extraction technology and identify the pesticides DDT, DDE and DDD, $\alpha-\mathrm{HCH}$ and $\Upsilon-\mathrm{HCH}$. OCP concentrations in ice core samples were highest at the 7-14 m depth $(0.51 \mathrm{ng} / \mathrm{L}$ of DDT) and decreased gradually approaching the bedrock at $79 \mathrm{~m}$. Meltwater concentrations from the proglacial creek slightly exceeded concentrations found in the ice core, potentially indicating aggregate OCP glacial loss, with peak OCP concentration (1.12 ng/L of DDD) taken in July and possibly associated to peak melt. Ongoing use of DDT to fight Malaria in Asia, and the extended atmospheric range of $\mathrm{HCH}$ may account for concentrations in near-surface ice of this remote glacier, correlating with use and atmospheric transport. The opportunity for bioaccumulation of OCPs, in humans or animals, of glacially distributed pollutants may increase as glacial melt continues.
\end{abstract}

Keywords: persistent pollutants 1; glaciers 2; Arctic 3

\section{Introduction}

Glaciers act as a reservoir for atmospherically deposited chemical compounds, providing a record of global anthropogenic chemical development and use.[1-3] Organochlorine pollutants (OCPs), manufactured as industrial additives and pesticides starting in the late 1800s and continuing until the enforcement of the Stockholm Convention in 2004, are a group of highly mobile toxic chemicals that have been found in alpine glaciers throughout the Northern hemisphere.[4,5]

Studies from Europe, Svalbard and western Canada have identified an OCP latitudinal gradient with highest chemical concentrations found in glaciers near $45^{\circ} \mathrm{N}$. This result implies that atmospheric transport of OCPs is ubiquitous, but that concentrations vary.[6-9] The highest OCP concentrations measured englacially, to date, were found in ice cores from the Italian Alps in 2001 (20 ng/L),[5] containing chemicals $\alpha$ - and $\Upsilon-\mathrm{HCH}$. While subsequent OCP studies in the Swiss Alps found concentrations of the same magnitude (PCB-12.5 ng/L),[6] all studies from the Arctic, including Svalbard (PCB- $1.5 \mathrm{ng} / \mathrm{L}$ )[7] and Canada (DDT- $2.5 \mathrm{ng} / \mathrm{L}$ ) $[9,10]$ have found lower OCP concentrations. The atmospheric range potential of each chemical is determined in part by distance from source, air mass transport, weight and volatility, with some pesticides able to redeposit multiple times.[6,7,10-14] $\Sigma \mathrm{HCH}$ has the greatest atmospheric range of all OCPs, due in part to its high volatility and low reactivity, which increases the probability of Arctic deposition.[15-19] 
Based upon this previous work, we hypothesized that it would be possible to identify an OCP signal within glaciers of the Interior Alaskan Arctic, where no OCP glacial sampling studies have been conducted.

Our recent assessment of screening level risk from glacially mobilized OCPs in the Swiss Alps identified potential cancer and disease risk from long-term fish consumption in the proglacial watershed.[20] Human consumption of local fish put health risk in the Swiss Alps just above screening level thresholds, even though the region is characterized by low levels of fish consumption.[20,21] The elevated fish consumption in subsistence groups of the Alaskan Arctic [22-24] indicates the need to explore the potential presence of OCPs in Alaskan glaciers and meltwater in order to characterize possible human health risks. Furthermore, Alaskan glaciers are losing mass at an increasing rate,[25-27] necessitating prompt study of OCP glacial entrainment to determine if pollutants are entering the glacier watershed below.

Jarvis Glacier represents one of the most well studied glacial systems in Eastern Alaska (Figure 1). $[23,28-30]$ Research into the connections between watershed characteristics, [28,29] permafrost [28] and ice dynamics have developed an integrated perspective of the glacier and the region. Ice core samples collected for investigation into Jarvis Glacier's ice dynamics give us opportunity to conduct the first study of OCPs entrained within a glacier of Interior Alaska, as a first effort to characterize species type and concentration. We identify the presence and concentration of OCPs pollutants in Jarvis Glacier watershed to add an understanding of glacially entrained pollutants to ongoing research on system dynamics.

There are relatively few historical and/or present uses of OCPs within Alaska, suggesting that any glacier-stored OCPs must be transported from distant locations. The use of DDT has been recorded within the last decade in China, India and DPR Korea,[31,32] with atmospheric transport across the Pacific $[19,33,34]$ and preferential OCP snow scavenging[13,35] increasing the likelihood of deposition onto Alaskan glaciers.[36-38] Recently retrieved ice core records from Interior Alaska indicate that the strengthening Aleutian low has resulted in increased snow deposition in the Alaska Range since 1840.[39] This increase of precipitation may allow for the greater success of OCP atmospheric scavenging and glacial deposition.[35,40] The potential for OCP deposition in Alaskan glaciers combined with recent elevated glacial mass loss in the Eastern Alaska Range [26,41] makes Jarvis Glacier an ideal case study for Alaskan glacial chemistry and potential for human OCP uptake.

\section{Summary}

Jarvis Glacier is a small glacier in the Interior of Alaska Eastern Range that has been found to contain harmful pesticide species $\Sigma \mathrm{DDT}$ and $\Sigma \mathrm{HCH}$. These compounds were discovered within both the glacier ice and meltwater during the 2016-2017 field season. While setting dates to the years of snow and ice deposition within the glacier was not possible, we are able to identify these same chemicals across all of the ice core and meltwater samples. Though these compounds are mostly banned today, we hypothesize that the DDT deposited near the surface of the glacier may have been transported atmospherically from Malaria-prevention efforts in Asia, whereas the $\mathrm{HCH}$ is known to be ubiquitous globally. As the compounds are introduced into the watershed, they may increase in concentration through biota bioaccumulation, potentially impacting subsistence populations disproportionately. Further research into the downstream impacts of glacially-released pollutants will be necessary to mitigate impacts across the Arctic and in glaciated regions.

\section{Materials and Methods}

Jarvis Glacier $\left(\sim 6 \mathrm{~km}^{2}\right)$ is a North facing, polythermal valley glacier in the Eastern Alaska Range of interior Alaska at $63.74 \mathrm{~N}$ latitude, $145.65 \mathrm{~W}$ longitude (Figure 1). The region is characterized by the semi-arid precipitation of a subarctic continental climate regime with a mean annual lowland 
precipitation accumulation of $303 \mathrm{~mm}$ and temperature of $-0.5^{\circ} \mathrm{C}$.[29] Summer warming in Interior Alaska of $0.1{ }^{\circ} \mathrm{C} \mathrm{yr} r^{-1}$ has resulted in a $12 \%$ glacier cover reduction and a continuously negative glacier mass balance across the Interior range for the last five decades.[28,42] Glacial meltwater from the range to the Tanana River (Figure 1) contributes up to $60 \%$ of annual downstream flow, and is increasing yearly.[30] Records identify that winter runoff increased in the proglacial Tanana River beginning in 1970's[43] in alignment with shrinking glaciers and aquifer recharge via glacierized headwater stream corridors, but without subsequent increase in precipitation. [28] Glacial contributions to stream flow have also been found to increase in June and July, concurrent with a yearly precipitation decrease ranging between $12-26 \%$, during the past 6 years.[29] This makes summer streamflow the period of greatest glacial discharge, and therefore presents the best opportunity to capture a glacial meltwater OCP signal.

For Jarvis Glacier, the seasonal warming and an absent compensation in solid precipitation have resulted in a $\sim 1600 \mathrm{~m}$ bare-ice retreat in the past 5 years, with an average of -3.0 m.w.e. yearly loss.[28] The glacier is currently in a state of overall mass loss characterized by a negligible accumulation area and significant yearly meltwater discharge from April-November, with internal temperatures fluctuating from $-10-0{ }^{\circ} \mathrm{C} .[29,44]$ Seasonal meltwater contribution for the near region oscillates monthly from $2 \%$ in May to $80 \%$ in September with an annual average of up to $35 \%$.[29] Locally, Jarvis Glacier feeds Jarvis Creek $\left(634 \mathrm{~km}^{2}\right)$ which flows year-round, including with a late winter discharge of approximately $3 \mathrm{~m}^{3} \mathrm{~s}^{-1} .[28]$ Glacial meltwater from Jarvis Glacier contributed $15 \%$ to $28 \%$ (in 2015 and 2016, respectively) of the annual runoff to Jarvis Creek watershed, which in turn feeds the larger Delta, Tanana and Yukon Rivers.[28]

\subsection{Ice Core}

In April 2017, a surface-to-bed (0-79 m) ice core was recovered from Jarvis Glacier. The ice core was retrieved using a 3 in. $(8.2 \mathrm{~cm})$ diameter Badger-Eclipse drill at the left lateral glacier margin in an area with folding, faulting and conjugate fractures (Figure 1). While the core was initially drilled to satisfy the objectives of a concurrent ice dynamics research study, drilling near the rapidly melting lateral margin also provides a more direct comparison between ice core and OCP stream samples. The ice core had alternating debris and melt layers, characteristic of a polythermal glacier, with clear layers containing bubble planes. Significant debris, englacial and basal water was discovered during drilling, and verified by ground penetrating radar profiles showing laterally extensive debris bands, water tables, and pockets of water (Figure 2). The combination of polythermal regime with diffuse annual ice and chemical layering, regular ice fracturing, and lateral margin drill location, make it impossible to determine chemical chronology of the core (Figure 1, 2). However, we hypothesize that with the glacier's length of $5 \mathrm{~km}$, and recent GPS measurements indicating an upper limit ice velocity approaching $25 \mathrm{~m} / \mathrm{yr}$., the lower age limit of Jarvis ice is 200 years. A recent increase in basal sliding velocity due to heat influx and increased melt may indicate a significantly higher upper age limit based upon a slower basal sliding velocity.

Once removed, the core was stored in a freezer on site at temperatures between -18 to $-20{ }^{\circ} \mathrm{C}$. Ice core sections were transported in 3-5 day intervals by helicopter to the Cold Regions Research and Engineering Laboratory (CRREL) in Fairbanks, Alaska, where they were stored at $-18{ }^{\circ} \mathrm{C}$. At CRREL, we retrieved $2 \mathrm{~L}$ of water equivalent from $7 \mathrm{~m}$ long segments of ice core, using a table saw cleaned and sanitized with ethanol and kept in a room at a constant temperature of $-18^{\circ} \mathrm{C}$. The segments were melted in chemically pre-cleaned, sealed one-gallon glass jars to prevent loss due to revolitilization. Once each section was melted, samples were filtered through C-18 Solid Phase Extraction (SPE) cartridges (Oasis HLB, $6 \mathrm{~cm}^{3} / 500 \mathrm{mg}$, LP Extraction Cartridge, $60 \mu \mathrm{m}$; Waters Corporation, Milford, Massachusetts, USA) to separate non-polar OCP compounds from polar organic material.[45-47] Following published protocol,[47] the C-18 cartridges were pre-cleaned with $5 \mathrm{ml}$ hexane and $5 \mathrm{ml}$ ethyl acetate followed by $5 \mathrm{ml}$ methanol and $5 \mathrm{ml}$ deionized water (Milli-Q). A tracing spike of $10 \mu \mathrm{l}$ of $100 \mathrm{ppm}$ organochlorine pesticides (Absolute standards, Hamden, CT) was added to one sample before filtration to measure method recovery, and $50 \mu \mathrm{l}$ of the recovery standard PCB $40\left(2,2^{\prime}, 3,3^{\prime}\right.$-Tetrachlorobiphenyl at a concentration of $10 \mathrm{ppm}$ in acetone, 
Chemservice, West Chester, PA) was also added to all samples. Samples were then drawn through cartridges using a vacuum manifold at a flow rate of approximately $10 \mathrm{ml} / \mathrm{min}$. After the extraction, the cartridges were dried under full vacuum pressure for $5 \mathrm{~min}$. and subsequently eluted with $3 \mathrm{ml}$ ethyl acetate and $5 \mathrm{ml}$ of hexane followed by a repeat elution of $5 \mathrm{ml}$ hexane. Samples were then blown down to a volume of $1 \mathrm{ml}$. A final extract $20 \mu \mathrm{l}$ of $100 \mathrm{ppm}$ internal standard

Tetrachloro-m-xylene (TCX) was added for continuity. After elution, the $1 \mathrm{ml}$ analytes were sealed and shipped directly to Anatek labs in Moscow, Idaho, for processing using triple quadrupole gas chromatography tandem mass spectrometry (GC-MS/MS) with the limit of detection at $0.1 \mathrm{ng} / \mathrm{L}$. Any sample concentrations found below the limit of detection are reported for reference only.

\subsection{Meltwater Samples}

Sampling of Jarvis Creek was accomplished using solid phase extraction (SPE) protocol.[45,46] 2 bulk water samples of $4 \mathrm{~L}$ each were taken to sample for particulates during the monthly sampling trips in 2016. From these we sampled 1 L using C-18 Solid Phase Extraction (SPE) cartridges (Sigma-Aldrich lab in St. Louis, MO) and processed samples at the University of Maine following the SPE methodology described in the Ice Core section. [47] Recovery standards and internal standards were added to all samples. All stream samples were analyzed at Anatek labs in Moscow, Idaho, using triple quadrupole gas chromatography tandem mass spectrometry (GC-MS/MS). 


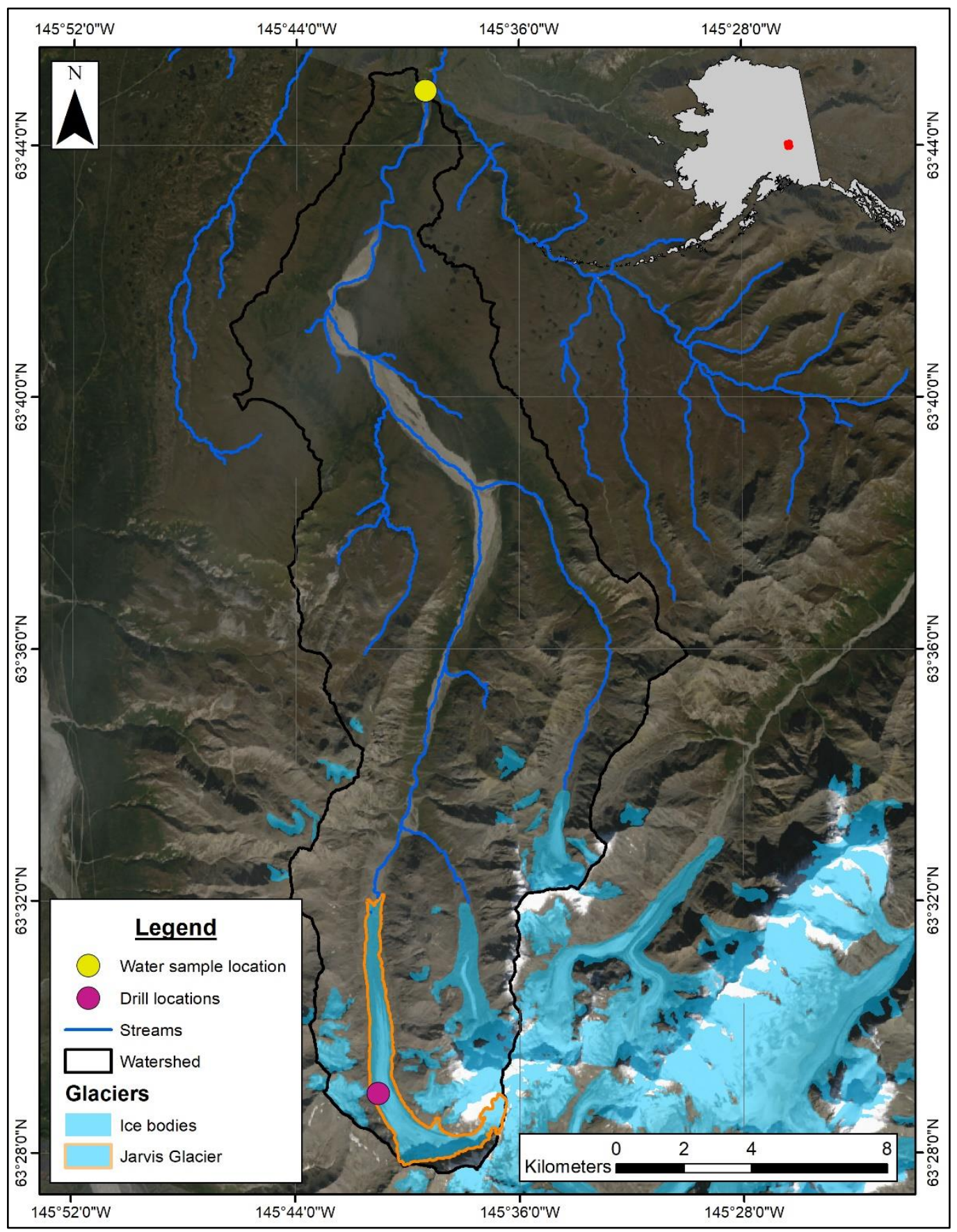

Figure 1. Map of Jarvis Glacier in the interior of Alaska. The bulk water sampling location in Jarvis Creek is indicated in yellow, an entirely glacier-fed tributary upstream of McCumber creek. 


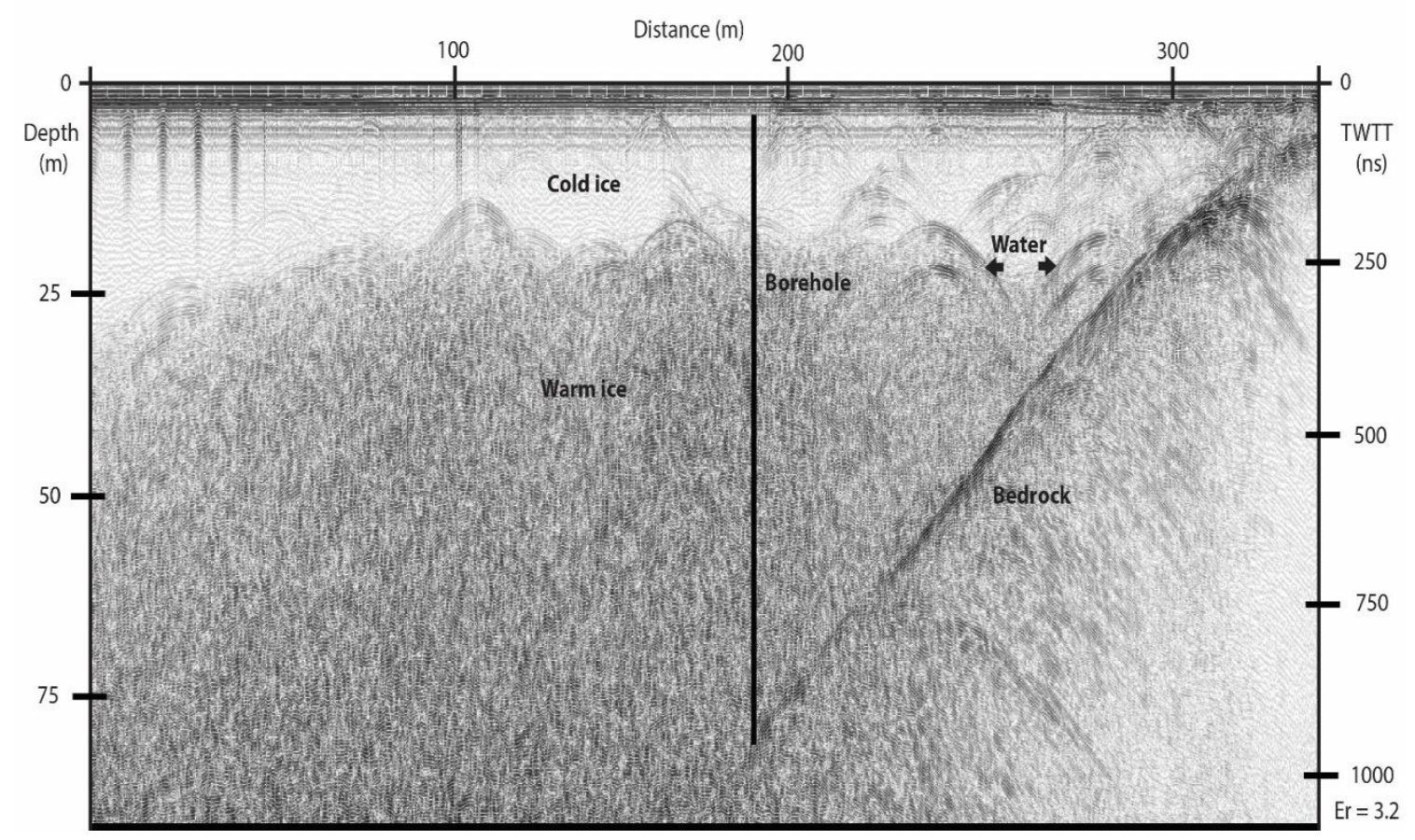

Figure 2. Radar profile for Jarvis Glacier $80 \mathrm{~m}$ borehole. Warm ice, cold ice and water in the transition between them are identified. Two-way travel time (TWTT) is indicated on the right axis.

\section{Results}

\subsection{Quality control}

The recovery standard PCB 40 (Chemservice, West Chester, PA) was recovered in ice core samples at an average $70 \% \pm 15 \%$ recovery and in meltwater samples to $80 \% \pm 15 \%$ recovery with blanks as a baseline. Recoveries were considered satisfactory across all analytes and are in alignment with recoveries from similar published protocols. $[7,48]$

SPE procedural blank process incorporates both lab and field results, as in-lab cleaning and SPE pre-activation with hexane, ethyl acetate and methanol is required. SPE blanks and spikes were generated using 1 L of Milli-Q water per filter, with Milli-Q water treated like a meltwater sample. Low level concentrations of OCPs were present in the blanks, at least 1-2 orders of magnitude lower than samples, contributing a negligible amount to concentrations. Reported sample values were thus not normalized for blanks. Bulk stream water samples from August 2016 contained significantly higher sediment quantities, leading to low recoveries and incomplete data, hence these samples were not reported here.

The instrumental GC-MS/MS uncertainty is based on the signal to noise ratio of the calibration method that contributes $\pm 15 \%$ to reported concentrations. GC-MS/MS detection calibration is determined after an initial demonstration of capability from the extraction of an instrumental blank followed by corrections based on variability measured within 4 spiked samples of known concentration. In this case, calibration (ICAL) was initiated for OCPs in levels ranging from 1000ppb to $10 \mathrm{ppb}$, where $1000 \mathrm{ppb}$ and $800 \mathrm{ppb}$ calibrations were neglected as the levels were too high in comparison to sample concentrations. Method detection limit procedure followed methods standardized by the EPA[49] for samples in water and was determined to be $0.1 \mathrm{ng} / \mathrm{L}$ for this method. 


\subsection{Patterns of OCPs in the ice core}

Out of the 18 pesticide compounds tested for in the Environmental Protection Agency method $8270 \mathrm{E}$, we found only 3 DDT species ( $\Sigma \mathrm{DDT})$ and $2 \mathrm{HCH}(\Sigma \mathrm{HCH})$ species in both the Jarvis ice core and meltwater (Figure 3,4).[50] Though the ice core chronology is not clear, we are able to determine the presence of OCPs in the entire ice core. Throughout the ice core we found greater quantities of $\Sigma D D T$ than $\Sigma \mathrm{HCH}$, with highest concentrations of all OCPs in ice core sections near the surface and peaking in the 7-14 m segment (Figure 3). Gradually lower concentrations occurred at lower depths, with $\Sigma$ DDT remaining highest in all layers.

Overall DDT was the OCP found at greatest quantities throughout the ice core (ice core total: 2.47, 7-14m peak: $0.51 \mathrm{ng} / \mathrm{L}$ ), followed by p, p'-DDE (ice core total: $1.53,7-14 \mathrm{~m}$ peak: $0.34 \mathrm{ng} / \mathrm{L}$ ) and p, $\mathrm{p}^{\prime}$-DDD (ice core total: 1.50, 7-14m peak: $0.45 \mathrm{ng} / \mathrm{L}$ ). Both $\alpha-\mathrm{HCH}$ (ice core total: 0.48, 7-14m peak: $0.15 \mathrm{ng} / \mathrm{L}$ ) and $\mathrm{Y}-\mathrm{HCH}$ were found at much lower concentrations throughout all layers (ice core total: $0.20,7-14 \mathrm{~m}$ peak: $0.15 \mathrm{ng} / \mathrm{L})$. Concentrations of both chemical groups found within the ice core were lower than concentrations found in the meltwater, potentially a result of increasing chemical loss from the ablating, polythermal glacier.

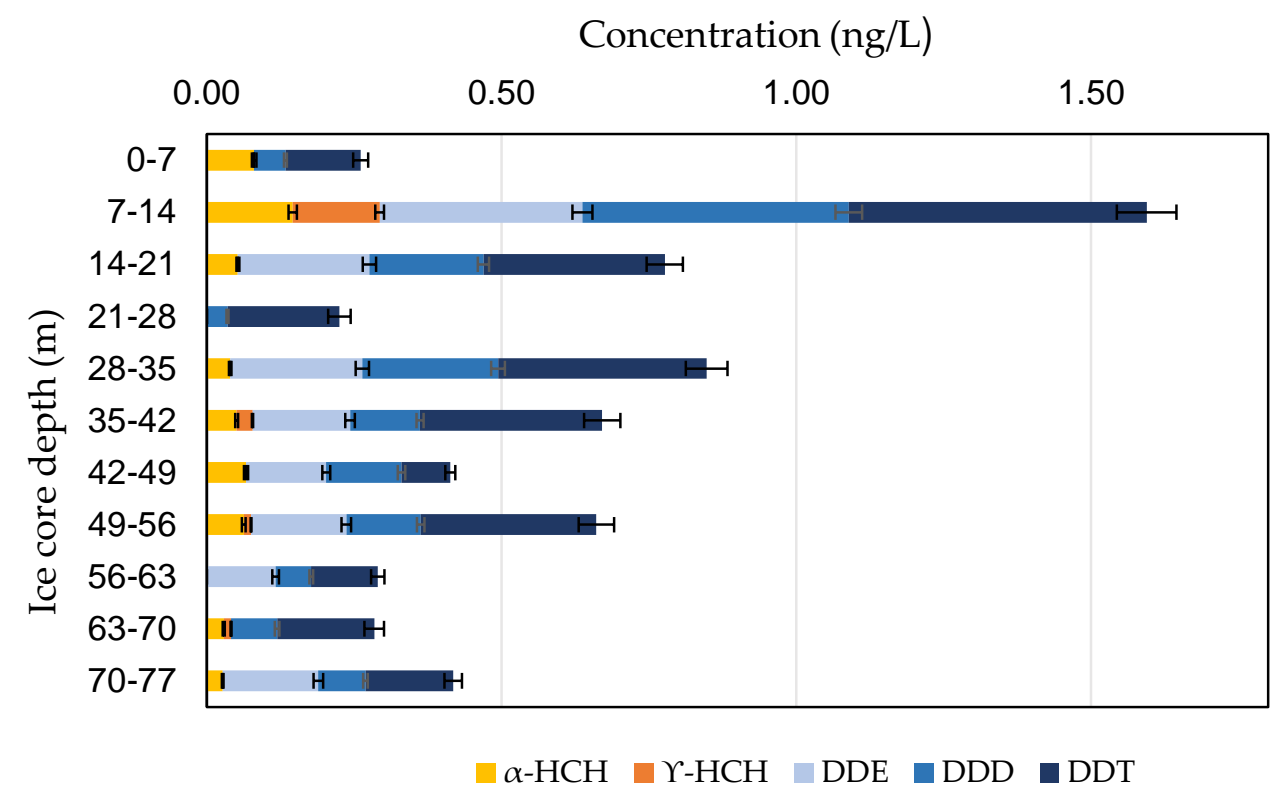

Figure 3. Stacked bar plot of ice core concentrations by depth from $0 \mathrm{~m}$ to $77 \mathrm{~m}$. 

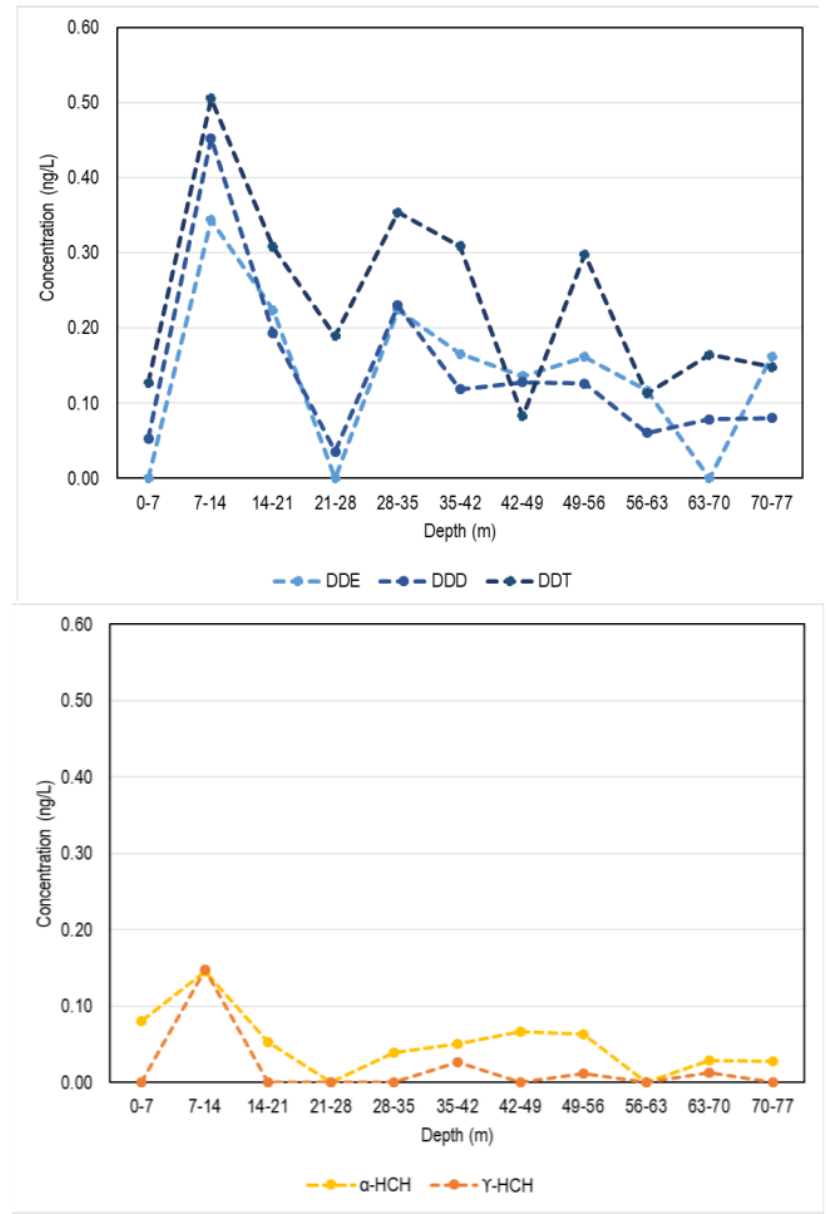

Figure 4. Ice core concentration trends by depth with DDT and HCH.

\subsection{Patterns of OCPs in meltwater}

Bulk meltwater samples showed greater concentrations of $\Sigma$ DDT than of $\Sigma H C H$, consistent with the results from ice core samples (Figure 5). For both June and July, p, p'-DDE was found in the greatest concentration (Average June: 0.69 , July: $0.73 \mathrm{ng} / \mathrm{L}$ ) throughout the bulk water samples, followed by p,p'-DDD (Average June: 0.60, July:0.56 ng/L) and DDT (Average June:0.58, July:0.47). Bulk water concentrations of $\alpha-\mathrm{HCH}$ and $\Upsilon-\mathrm{HCH}$ were again in slightly lower concentrations while $\Upsilon$-HCH concentrations (Average June: 0.36 , July:0.32 ng/L) were slightly above $\alpha$-HCH (Average June: 0.27, July: $0.19 \mathrm{ng} / \mathrm{L})$. 


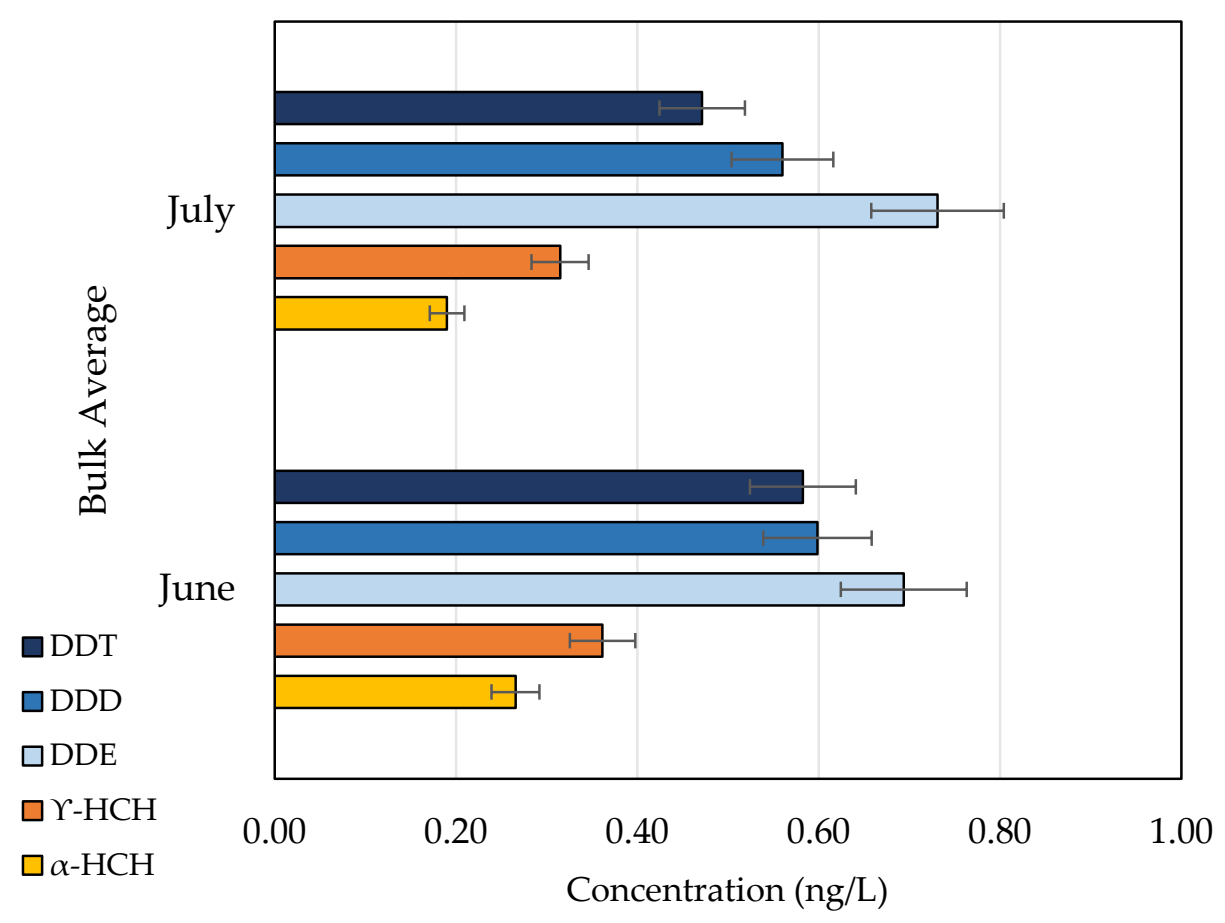

Figure 5. Bulk meltwater concentrations by month sampled.

\section{Discussion}

\subsection{Ice core OCP concentrations}

The Jarvis Glacier polythermal regime, combined with recent warming trends, result in high water mobility between ice layers and below glacier, mobilizing particulates and increasing basal lubrication.[51] There was significant meltwater and mineral particulates found at the bottom of the borehole and throughout the ice layers within Jarvis Glacier. Debris at the bed also increases basal porosity and deep-water flow, increasing the potential for OCP entrainment and transport. Additionally, sediment inputs from the glacier bed or walls may increase OCP sorbtion to material and transport out of the glacier. This may account for lower concentrations of OCPs in ice as compared to meltwater, as englacial and basal flow ultimately drains to the stream below the terminal ice margin. Particle sorbtion within Jarvis' sediment-rich ice layers may increase OCP loss during englacial and supraglacial melt events.[52-54] Ice core concentrations indicate that $\Sigma D D T$ is the greatest contributor to OCP concentrations within Jarvis Glacier. $\Sigma$ DDT deposition may be a result of use prior to the Stockholm Convention ban, however, continuing DDT use in Asia to combat malaria may explain why comparatively elevated rates occur in samples proximal to the surface.[31,32,34,37]

\subsection{Patterns of atmospheric deposition}

Though the Arctic is geographically distant from a majority of OCP use areas, the interconnected atmosphere-cryosphere system reflects the global mobilization of human-use chemicals.[40] Atmospheric transport of $\Sigma$ DDT from Asia where it is used for fighting Malaria[31,32,34,37] may account for comparatively elevated rates in our samples. Research into Alaskan ice core dust has used satellite images and back trajectories to identify North Pacific atmospheric transport as a source of particulates to Alaska.[34,36,38] NOAA's HYSPLIT back trajectories corroborate published findings that a 10-day period is sufficient for air masses containing pollution from Asia to travel to the North Pacific and Alaska.[37,55] Pollution carried in these air masses could be deposited on glaciers through snow scavenging during a period of mass 
gain[53,56] or through permeation into supraglacial storage during a period of mass loss.[29] Supraglacial melt in the spring may introduce these recently deposited pollutants immediately into the downstream watershed throughout the range.[53] We speculate, based upon transport analysis, that OCP deposition in Interior Alaska is not limited to Jarvis Glacier, but is reflected throughout the Eastern Alaska Range.

Jarvis Glacier ice core samples show lower OCP concentrations than those recorded in other Arctic studies, $[48,54]$ which may be a product of loss due to melt, or the distant location of Jarvis Glacier from regions of greatest use. $[48,54]$ This is in line with a latitudinal OCP concentration gradient noted by previous studies that identifies lower concentration within glaciers North of 65 ${ }^{\circ}$ N.[9,57] The higher quantities of $\Sigma D D T$ and $\Sigma \mathrm{HCH}$ found in the glacial meltwater as compared to the ice core may correlate with increased atmospheric warming and subsequent melt over the last 6 years.[29,47,51,54]

\subsection{Meltwater transport and OCP dynamics downstream}

As discussed, Jarvis' polythermal structure raises the possibility of supraglacial water moving OCPs englacially to the sub-glacier environment.[51] However, the permafrost-rich environment below Jarvis Glacier may pose additional routes for storage and release of OCPs over time. Pooling within the proglacial permafrost may temporarily stall the movement of OCPs flowing into the larger watershed, with subsequent permafrost thaw increasing the potential for tertiary OCP release.[58] Stream sediments below the glacier can also act as short-term storage with release dependent on water transport, bioturbation, or direct sediment transport.[59,60] A complete understanding of the type and location of OCPs found in alpine environments will be critical in order to protect the biota from sudden pollutant influx. Though the secondary and tertiary emergence of these chemicals will not reflect the pollution problems of industrial watersheds, OCP bioaccumulation in the ecosystem may cause long-term health impacts in certain populations.

\subsection{Implications for Arctic populations and ecosystems}

Presence of OCPs within Jarvis Glacier and remote Interior Alaska reaffirms the ubiquitous transport and deposition of OCPs within the high Northern latitudes. It is likely that Jarvis Glacier is not an isolated case and that numerous glaciers in the Eastern Alaska Range house legacy OCPs. In line with glacial melt contribution to the watershed,[30] numerous glaciers releasing stored legacy chemicals into the ecosystem may raise the concentration of OCPs above background levels. Subsistence Arctic populations that eat exclusively from the local biota could therefore be indicated for potential human health impacts.[20]

Though the concentrations of $\Sigma \mathrm{DDT}$ and $\mathrm{\Sigma HCH}$ found within Jarvis Glacier ice and meltwater are low, the potential for bioaccumulation through the proglacial food chain $[15,61,62]$ and the human population $[63,64]$ increases their potential impact. As mentioned, within the Tanana River, glacial meltwater currently accounts for over $50 \%$ of annual stream flow,[30] consistently introducing OCPs into the watershed.[28,53,54] This OCP transport may occur within other ablating glaciers of Interior Alaska, raising the possibility that OCP concentration in the ecologically critical Yukon watershed is increasing with ongoing glacial melt.[9,62,65-68] Thus, investigations into the reemergence and distribution of OCPs in Arctic glaciers should be prioritized. With the high fish consumption of many Arctic subsistence groups,[24] the risk of toxicity from OCP bioaccumulation is higher than other alpine regions.

\section{Conclusions}

Our work adds a new North American Arctic data set to the research of OCPs in glaciers, while reaffirming the ongoing deposition of OCPs into Arctic ecosystems.[11,17,19,69] The entrainment of chemicals in a remote Interior Alaskan glacier reiterates the transport and deposition of 
organochlorine compounds globally and the increasing need to assess human health risks from glacial meltwater. Though these chemicals are found in trace quantities within Jarvis Glacier, they introduce OCPs into the watershed at levels higher than direct atmospheric deposition.

As atmospherically deposited pollutants emerge from glacial environments under a warming climate, the health risks from bioaccumulation in the food chain may be compounding. Detailed risk assessment modeling that incorporates bioaccumulation would help elucidate the potential for concentration increase and uptake. Emergent pollution from melting glaciers is one of the lesser known consequences of climate change that represent an area of critical research importance. Though OCPs are only one contributor to emergent pollution within glacial ecosystems, they form part of a greater picture of the long-term fingerprint humans have left on even the most remote locations.

Author Contributions: Conceptualization, K. Miner, K. Kreutz, A. Liljedahl, C. Gerbi.; Methodology, K. Miner, T. Anderson; Formal Analysis, K. Miner, T. Anderson, S. Campbell, K. Kreutz; Investigation, K. Miner, S. Campbell, S. Bernsen; Resources, C. Gerbi, K. Kreutz, S. Campbell.; Data Curation, K. Miner.; Writing-Original Draft Preparation, K. Miner.; Writing-Review \& Editing, K. Kreutz, S. Campbell, A. Liljedahl, C. Gerbi.; Visualization, K. Miner, S. Campbell.; Supervision, K. Kreutz, S. Campbell; Project Administration, K. Miner; Funding Acquisition, K. Miner.

Funding: KR Miner and the Jarvis field team 2016 were supported by the Switzer Foundation, SMART Scholarship and NSF grant DGE- 1144423.

Acknowledgments: The authors would like to thank the field team that contributed immeasurably to this work, including CRREL and Tom Douglas, Ice Drilling and Design Operations, Robert Hawley at Dartmouth, Stephanie Mills and Aaron Chesler at University of Maine. We would also like to thank Jesse Walters, Anatek Labs and Walter Beckwith for assistance with the manuscript.

Conflicts of Interest: “The authors declare no conflict of interest.”

\section{References}

1. Blais, J. M.; Schindler, D. W.; Muir, D. C. G.; Sharp, M.; Donald, D.; Lafrenière, M.; Braekevelt, E.; Strachan, W. M. J. Melting glaciers: a major source of persistent organochlorines to subalpine Bow Lake in Banff National Park, Canada. Ambio 2001, 30, 410-415, doi:10.1639/0044-7447(2001)030[0410:mgamso]2.0.co;2.

2. Bogdal, C.; Schmid, P.; Zennegg, M.; Anselmetti, F. S.; Scheringer, M.; Hungerbühler, K. Blast from the past: melting glaciers as a relevant source for persistent organic pollutants. Environ. Sci. Technol. 2009, 43, 8173-7, doi:10.1021/es901628x.

3. Villa, S.; Vighi, M.; Maggi, V.; Finizio, A.; Bolzacchini, E. Historical trends of organochlorine pesticides in an Alpine glacier. J. Atmos. Chem. 2003, 46, 295-311, doi:10.1023/A:1026316217354.

4. Grannas, A. M.; Bogdal, C.; Hageman, K. J.; Halsall, C.; Harner, T.; Hung, H.; Kallenborn, R.; Klán, P.; Klánová, J.; Macdonald, R. W.; Meyer, T.; Wania, F. The role of the global cryosphere in the fate of organic contaminants. Atmos. Chem. Phys. 2013, 13, 3271-3305, doi:10.5194/acp-13-3271-2013.

5. Villa, S.; Maggi, V.; Negrelli, C.; Finizio, A.; Bolzacchini, E.; Vighi, M. Historical profile of polychlorinated biphenyls (PCBs) in an alpine glacier. Fresenius Environ. Bull. 2001, 10, 711- 
716.

6. Pavlova, P. A.; Schmid, P.; Bogdal, C.; Steinlin, C.; Jenk, T. M.; Schwikowski, M. Polychlorinated biphenyls in glaciers. 1. Deposition history from an Alpine ice core. Environ. Sci. Technol. 2014, 48, 7842-8, doi:10.1021/es5017922.

7. Garmash, O.; Hermanson, M. H.; Isaksson, E.; Schwikowski, M.; Divine, D.; Teixeira, C.; Muir, D. C. G. Deposition history of polychlorinated biphenyls to the lomonosovfonna glacier, Svalbard: A 209 congener analysis. Environ. Sci. Technol. 2013, 47, 12064-12072, doi:10.1021/es402430t.

8. Blais, J. M.; Schindler, D. W.; Muir, D. C. G.; Kimpe, L. E.; Donald, D. B.; Rosenberg, B. Accumulation of persistent organochlorine compounds in mountains of western Canada. Nature 1998, 395, 585-588, doi:Doi 10.1038/26944.

9. Miner, K. R.; Blais, J.; Bogdal, C.; Villa, S.; Schwikowski, M.; Pavlova, P.; Steinlin, C.; Gerbi, C.; Kreutz, K. J. Legacy organochlorine pollutants in glacial watersheds: A review. Environ. Sci. Process. Impacts 2017, 19, 1-10, doi:10.1039/c7em00393e.

10. Donald, D. B.; Syrgiannis, J.; Crosley, R. W.; Holdsworth, G.; Muir, D. C. G.; Rosenberg, B.; Sole, A.; Schindler, D. W. Delayed deposition of organochlorine pesticides at a temperate glacier. Environ. Sci. Technol. 1999, 33, 1794-1798, doi:10.1021/es981120y.

11. Burkow, I. C.; Kallenborn, R. Sources and transport of persistent pollutants to the Arctic. Toxicol. Lett. 2000, 112-113, 87-92, doi:10.1016/S0378-4274(99)00254-4.

12. Friedman, C. L.; Selin, N. E. PCBs in the Arctic atmosphere: determining important driving forces using a global atmospheric transport model. Atmos. Chem. Phys. 2016, 16, 3433-3448, doi:10.5194/acpd-15-30857-2015.

13. Friedman, C. L.; Selin, N. E. Long-range atmospheric transport of polycyclic aromatic hydrocarbons: A global 3-D model analysis including evaluation of arctic sources. Environ. Sci. Technol. 2012, 46, 9501-9510, doi:10.1021/es301904d.

14. Hauptmann, A. L.; Sicheritz-Pontén, T.; Cameron, K. A.; Bælum, J.; Plichta, D. R.; Dalgaard, M.; Stibal, M. Contamination of the Arctic reflected in microbial metagenomes from the Greenland ice sheet. Environ. Res. Lett. 2017, 12, 074019, doi:10.1088/1748-9326/aa7445.

15. Daly, G. L.; Wania, F. Critical Review Organic Contaminants in Mountains. Environ. Sci. Technol. 2005, 39, 385-398, doi:10.1021/es048859u.

16. Helm, P. a; Diamond, M. L.; Semkin, R.; Strachan, W. M. J.; Teixeira, C.; Gregor, D. A mass balance model describing multiyear fate of organochlorine compounds in a high Arctic lake. Environ. Sci. Technol. 2002, 36, 996-1003, doi:10.1021/es010952k.

17. Shen, L.; Wania, F.; Lei, Y. D.; Teixeira, C.; Muir, D. C. G.; Bidleman, T. F. Hexachlorocyclohexanes in the North American atmosphere. Environ. Sci. Technol. 2004, 38, 
965-975, doi:10.1021/es034998k.

18. Hansen, K. M.; Christensen, J. H.; Geels, C.; Silver, J. D.; Brandt, J. Modelling the impact of climate change on the atmospheric transport and the fate of persistent organic pollutants in the Arctic. Atmos. Chem. Phys. 2015, 15, 6549-6559, doi:10.5194/acp-15-6549-2015.

19. Octaviani, M.; Stemmler, I.; Lammel, G.; Graf, H. F. Atmospheric transport of persistent organic pollutants to and from the arctic under present-day and future climate. Environ. Sci. Technol. 2015, 49, 3593-3602, doi:10.1021/es505636g.

20. Miner, K. R.; Bogdal, C.; Pavlova, P. A.; Steinlin, C.; Kreutz, K. J. Quantitative screening level assessment of human risk from PCB in glacial meltwater: Silvretta Glacier, Swiss Alps. 2018, In review.

21. Statistical Office, S. F. Food and Agriculture Statistics; Zurich, Switzerland, 2017;

22. Conservation, A. D. of E. Alaska Department of Environmental Conservation Office of the State Veterinarian Fish Monitoring Program Organochlorine Pesticides in Alaska's Fishes; Anchorage, AK, 2017;

23. Fall, J. A.; Brenner, A. R.; Evans, S. S.; Holen, D.; Hutchinson-Scarbrough, L.; Jones, B.; Vine, R. La; Lemons, T.; Marchioni, M. A.; Mikow, E.; Ream, J. T.; Sill, L. A.; Trainor, A. Alaska subsistence and personal use salmon fisheries 2011 annual report; 2013; ISBN 1800478364.

24. Ballew, C.; Ross, A.; Wells, R. S.; Hiratsuka, V. Final report on the Alaska traditional diet survey; Fairbanks, 2004;

25. Hock, R. Glacier Mass Balance. Summer Sch. Glaciol. - Fairbanks/McCarthy 2010, 1-10, doi:10.1007/978-94-007-6311-1_6.

26. Zemp, M.; Frey, H.; Gärtner-Roer, I.; Nussbaumer, S. U.; Hoelzle, M.; Paul, F.; Haeberli, W.; Denzinger, F.; Ahlstrøm, A. P.; Anderson, B.; Bajracharya, S.; Baroni, C.; Braun, L. N.; Càceres, B. E.; Casassa, G.; Cobos, G.; Dàvila, L. R.; Delgado Granados, H.; Demuth, M. N.; Espizua, L.; Fischer, A.; Fujita, K.; Gadek, B.; Ghazanfar, A.; Hagen, J. O.; Holmlund, P.; Karimi, N.; Li, Z.; Pelto, M.; Pitte, P.; Popovnin, V. V.; Portocarrero, C. A.; Prinz, R.; Sangewar, C. V.; Severskiy, I.; Sigurdsson, O.; Soruco, A.; Usubaliev, R.; Vincent, C. Historically unprecedented global glacier decline in the early 21st century. J. Glaciol. 2015, 61, 745-762, doi:10.3189/2015JoG15J017.

27. Mountain Research Initiative E D W Working Elevation-dependent warming in mountain regions of the world. Nat. Clim. Chang. 2015, 5, 424-430, doi:10.1038/nclimate2563 \rhttp://www.nature.com/nclimate/journal/v5/n5/abs/nclimate2563 .html\#supplementary-information.

28. Liljedahl, A. K.; Gädeke, A.; O’Neel, S.; Gatesman, T. A.; Douglas, T. A. Glacierized headwater streams as aquifer recharge corridors, subarctic Alaska. Geophys. Res. Lett. 2017, 
6876-6885, doi:10.1002/2017GL073834.

29. Gatesman, T. A. Glacier contribution to lowland streamflow, University of Alaska, Fairbanks, 2017.

30. Wada, T.; Chikita, K. A.; Kim, Y.; Kudo, I. Glacial effects on discharge and sediment load in the subarctic Tanana River basin. Alaska, Arctic, Antarct. Alp. Res. 2011, 43, 632-648, doi:10.1657/1938-4246-43.4.632.

31. van den Berg, H.; Manuweera, G.; Konradsen, F. Global trends in the production and use of DDT for control of malaria and other vector-borne diseases. Malar. J. 2017, 16, 401, doi:10.1186/s12936-017-2050-2.

32. Wang, X. ping; Xu, B. qing; Kang, S. chang; Cong, Z. yuan; Yao, T. dong The historical residue trends of DDT, hexachlorocyclohexanes and polycyclic aromatic hydrocarbons in an ice core from Mt. Everest, central Himalayas, China. Atmos. Environ. 2008, 42, 6699-6709, doi:10.1016/j.atmosenv.2008.04.035.

33. Toose, L.; Woodfine, D. G.; MacLeod, M.; MacKay, D.; Gouin, J. BETR-World: A geographically explicit model of chemical fate: Application to transport of $\alpha-\mathrm{HCH}$ to the Arctic. Environ. Pollut. 2004, 128, 223-240, doi:10.1016/j.envpol.2003.08.037.

34. Stein, A. F.; Draxler, R. R.; Rolph, G. D.; Stunder, B. J. B.; Cohen, M. D.; Ngan, F. Noaa's hysplit atmospheric transport and dispersion modeling system. Bull. Am. Meteorol. Soc. 2015, 96, 2059-2077, doi:10.1175/BAMS-D-14-00110.1.

35. Lei, Y. D.; Wania, F. Is rain or snow a more efficient scavenger of organic chemicals? Atmos. Environ. 2004, 38, 3557-3571, doi:10.1016/j.atmosenv.2004.03.039.

36. Osterberg, E. C.; Mayewski, P.; Kreutz, K.; Fisher, D.; Handley, M.; Sneed, S.; Zdanowicz, C.; Zheng, J.; Demuth, M.; Waskiewicz, M.; Bourgeois, J. Ice core record of rising lead pollution in the North Pacific atmosphere. Geophys. Res. Lett. 2008, 35, 2-5, doi:10.1029/2007GL032680.

37. Yasunari, T. J.; Yamazaki, K. Origins of Air Masses over an Alaskan Glacier and Implications for Ice Core Studies in the North Pacific Region. Sola 2009, 5, 77-80, doi:10.2151/sola.2009-020.

38. Osterberg, E. C.; Winski, D. A.; Kreutz, K. J.; Wake, C. P.; Ferris, D. G.; Campbell, S.; Introne, D.; Handley, M.; Birkel, S. The 1200 year composite ice core record of Aleutian Low intensification. Geophys. Res. Lett. 2017, 7447-7454, doi:10.1002/2017GL073697.

39. Winski, D.; Osterberg, E.; Kreutz, K.; Wake, C.; Ferris, D.; Campbell, S.; Baum, M.; Bailey, A.; Birkel, S.; Introne, D.; Handley, M. A 400-year ice core melt layer record of summertime warming in the Alaska Range. Sci. Rep. 2017, 7, doi:10.1038/s41598-017-18022-5.

40. Morselli, M.; Semplice, M.; Villa, S.; Di Guardo, A. Evaluating the temporal variability of concentrations of POPs in a glacier-fed stream food chain using a combined modeling approach. Sci. Total Environ. 2014, 493, 571-579, doi:10.1016/j.scitotenv.2014.05.150. 
41. WGMS Global Glacier Change Bulletin; Zurich, Switzerland, 2015; Vol. 1;.

42. O'Neel, S.; Hood, E.; Arendt, A.; Sass, L. Assessing streamflow sensitivity to variations in glacier mass balance. Clim. Chang. 2014, 123, 329-341, doi:10.1007/s10584-013-1042-7.

43. Brabets, T. P.; Walvoord, M. A. Trends in streamflow in the Yukon River basin from 1944 to 2005, and the influence of the Pacific Decadal Oscillation. J. Hydrol. 2009, 371, 108-119, doi:10.1016/j.jhydrol.2009.03.018.

44. Ian Lee Personal Communication 2017, Masters Student. Dartmouth University.

45. Fortuny, G.; Pineda, L.; Rúbies, A.; Centrich, F.; Companyó, R. Determination of 61 organic pollutants in drinking water by solid phase extraction followed by liquid and gas chromatography coupled to tandem mass spectrometry: an analytical strategy for a routine laboratory. Int. J. Environ. Anal. Chem. 2013, 93, 707-726, doi:10.1080/03067319.2011.649745.

46. (EPA), U. S. E. P. A. Method 3535 A: Solid Phase Extraction (SPE) 2007, 1-23.

47. Ferrario, C.; Finizio, A.; Villa, S. Legacy and emerging contaminants in meltwater of three Alpine glaciers. Sci. Total Environ. 2017, 574, 350-357, doi:10.1016/j.scitotenv.2016.09.067.

48. Hermanson, M. H.; Isaksson, E.; Teixeira, C.; Muir, D. C. G.; Compher, K. M.; Li, Y. F.; Igarashi, M.; Kamiyama, K. Current-use and legacy pesticide history in the Austfonna ice cap, Svalbard, Norway. Environ. Sci. Technol. 2005, 39, 8163-8169, doi:10.1021/es051100d.

49. (EPA), U. S. E. P. A. Definition and Procedure for the Determination of the Method Detection Limit. 2014.

50. (EPA), U. S. E. P. A. Method 8270: Semivolatile organic compounds by gas chromatography/mass spectrometry; 1998;

51. Pavlova, P. A.; Zennegg, M.; Anselmetti, F. S.; Schmid, P.; Bogdal, C.; Steinlin, C.; Jaggi, M.; Schwikowski, M. Release of PCBs from Silvretta glacier (Switzerland) investigated in lake sediments and meltwater. Environ. Sci. Pollut. Res. 2016, 23, 10308-10316, doi:10.1007/s11356-015-5854-z.

52. Pavlova, P. A.; Jenk, T. M.; Schmid, P.; Bogdal, C.; Steinlin, C.; Schwikowski, M. Polychlorinated Biphenyls in a Temperate Alpine Glacier: 1. Effect of Percolating Meltwater on their Distribution in Glacier Ice. Environ. Sci. Technol. 2015, 49, 14085-14091, doi:10.1021/acs.est.5b03303.

53. Steinlin, C.; Bogdal, C.; Pavlova, P. A.; Schwikowski, M.; Lüthi, M. P.; Scheringer, M.; Schmid, P.; Hungerbühler, K. Polychlorinated Biphenyls in a Temperate Alpine Glacier: 2. Model Results of Chemical Fate Processes. Environ. Sci. Technol. 2015, 49, 14092-14100, doi:10.1021/acs.est.5b03304.

54. Steinlin, C.; Bogdal, C.; Lüthi, M. P.; Pavlova, P. A.; Schwikowski, Margit Zennegg, M.; 
Schmid, P.; Scheringer, Martin Hungerbühler, K. A Temperate Alpine Glacier as a Reservoir of Polychlorinated Biphenyls: Model Results of Incorporation, Transport, and Release. Environ. Sci. Technol. 2016, 50, 5572-5579, doi:10.1021/acs.est.5b05886.

55. Yasunari, T. J.; Shiraiwa, T.; Kanamori, S.; Fujii, Y.; Igarashi, M.; Yamazaki, K.; Benson, C. S.; Hondoh, T. Intra-annual variations in atmospheric dust and tritium in the North Pacific region detected from an ice core from Mount Wrangell, Alaska. J. Geophys. Res. Atmos. 2007, 112, 1-16, doi:10.1029/2006JD008121.

56. Steinlin, C.; Bogdal, C.; Scheringer, M.; Pavlova, P. A.; Schwikowski, M.; Schmid, P.; Hungerbühler, K. Polychlorinated biphenyls in glaciers. 2. Model results of deposition and incorporation processes. Environ. Sci. Technol. 2014, 48, 7849-57, doi:10.1021/es501793h.

57. Daly, G. L.; Wania, F. Organic Contaminants in Mountains. Environ. Sci. Technol. 2005, 39, 385-398, doi:10.1021/es048859u.

58. Ma, J.; Hung, H.; Tian, C.; Kallenborn, R. Revolatilization of persistent organic pollutants in the Arctic induced by climate change. Nat. Clim. Chang. 2011, 1, 255-260, doi:10.1038/nclimate1167.

59. Schmid, P.; Bogdal, C.; Bluthgen, N.; Anselmetti, F. S.; Zwyssig, A.; Hungerbuhler, K. The Missing Piece: Sediment Records in Remote Mountain Lakes Confirm Glaciers Being Secondary Sources of Persistent Organic Pollutants. Environ. Sci. Technol. 2011, 45, 203-208, doi:10.1021/es1028052.

60. van Drooge, B.; Garriga, G.; Koinig, K.; Psenner, R.; Pechan, P.; Grimalt, J. Sensitivity of a Remote Alpine System to the Stockholm and LRTAP Regulations in POP Emissions. Atmosphere (Basel). 2014, 5, 198-210, doi:10.3390/atmos5020198.

61. Davidson, D. A.; Wilkinson, A. C.; Blais, J. M.; Kimpe, L. E.; McDonald, K. M.; Schindler, D. $\mathrm{W}$. Orographic cold-trapping of persistent organic pollutants by vegetation in mountains of western Canada. Environ. Sci. Technol. 2003, 37, 209-215, doi:10.1021/es020605q.

62. Blais, J. M.; Wilhelm, F.; Kidd, K. A.; Muir, D. C. G.; Donald, D. B.; Schindler, D. W. Concentrations of organochlorine pesticides and polychlorinated biphenyls in amphipods (Gammarus lacustris) along an elevation gradient in mountain lakes of western Canada. Environ. Toxicol. Chem. 2003, 22, 2605-2613, doi:10.1897/02-389.

63. Dassanayake, R. M. A. P. S. Legacy and Emerging Environmental Organic Pollutants in Human Placenta and Blood. Diss. Igarss 2014 2014, 1-188, doi:10.1007/s13398-014-0173-7.2.

64. Czub, G.; McLachlan, M. S. Bioaccumulation Potential of Persistent Organic Chemicals in Humans. Environ. Sci. Technol. 2004, 38, 2406-2412, doi:10.1021/es034871v.

65. Bizzotto, E. C.; Villa, S.; Vighi, M. POP bioaccumulation in macroinvertebrates of alpine freshwater systems. Environ. Pollut. 2009, 157, 3192-3198, 
doi:http://dx.doi.org/10.1016/j.envpol.2009.06.001.

66. Jaacks, L. M.; Staimez, L. R. Association of persistent organic pollutants and non-persistent pesticides with diabetes and diabetes-related health outcomes in Asia: A systematic review. Environ. Int. 2015, 76, 57-70, doi:10.1016/j.envint.2014.12.001.

67. Vizcaino, E.; Grimalt, J. O.; Fernandez-Somoano, A.; Tardon, A. Transport of persistent organic pollutants across the human placenta. Environ. Int. 2014, 65, 107-115, doi:10.1016/j.envint.2014.01.004.

68. Iszatt, N.; Stigum, H.; Verner, M.-A.; White, R. A.; Govarts, E.; Murinova, L. P.; Schoeters, G.; Trnovec, T.; Legler, J.; Pelé, F.; Botton, J.; Chevrier, C.; Wittsiepe, J.; Ranft, U.; Vandentorren, S.; Kasper-Sonnenberg, M.; Klümper, C.; Weisglas-Kuperus, N.; Polder, A.; Eggesbø, M. Prenatal and Postnatal Exposure to Persistent Organic Pollutants and Infant Growth: A Pooled Analysis of Seven European Birth Cohorts. Environ. Health Perspect. 2015, 123, 730-6, doi:10.1289/ehp.1308005.

69. Simonich, S. L.; Hites, R. A. Global Distribution of Persistent Organic Compounds. Science (80). 1995, 269, 1851-1853. 